\title{
Diseño y aplicación de estrategias andragógicas comunicativas en el centro universitario de idiomas de la Universidad Central del Ecuador
}

\section{Design and application of communicative andragogic strategies in the university language center of the Central University of Ecuador}

\section{Projeto e aplicação de estratégias andragógicas comunicativas no centro de idiomas da Universidade Central do Equador}

\begin{abstract}
Marco V. Mier-Urbina ${ }^{I}$ mvmier@uce.edu.ec

Manuel W. Alvarado-Miles mwalvarado@uce.edu.ec
\end{abstract}

\author{
María G. Figueroa-Arellano ${ }^{\text {IV }}$ \\ mgfigueroa@uce.edu.ec \\ Francisco D. Sandoval-Ortiz \\ fdsandoval@uce.edu.ec
}

Edison A. Almachi-Montahuano

eaalmachi@uce.edu.ec

III

Correspondencia: mvmier@uce.edu.ec

I. Magister en Linguistica Aplicada a la enseñanza Bilingue Español-Inglés; Magister en Gerencia y Liderazgo Educacional; Licenciado en Ciencias de la Educación mención Ingles; Universidad Central del Ecuador, Quito, Ecuador.

II. Magister en Gerencia y Liderazgo Educacional; Licenciado en Ciencias de la Educación Mención Ingles; Tecnólogo En Administración de Empresas; Técnico Superior en Administración de Empresas; Universidad Central del Ecuador, Quito, Ecuador.

III. Magister en Linguistica Aplicada a la Enseñanza Bilingue Español-Inglés; Licenciado en Ciencias de la Educación Mención Ingles; Técnico Superior en Análisis de Sistemas; Tecnólogo en Sistemas de Automatización; Universidad Central del Ecuador, Quito, Ecuador.

IV. Master of Science in Curriculum and Instruction, English as a Second Language; Ingeniera en Gestión Turística y Medio Ambiente; Guía de Turismo; Universidad Central del Ecuador, Quito, Ecuador.

v. Magister en Docencia Universitaria y Administración Educativa; Licenciado en Ciencias de la Educación Mención Ingles; Universidad Central del Ecuador, Quito, Ecuador. 


\section{Resumen}

La presente investigación fue fundamentada en la aplicación de Estrategias Andragógicas para el desarrollo de la Producción Oral del idioma inglés de los estudiantes del nivel A2 del Centro Universitario de Idiomas de la Universidad Central del Ecuador durante el período correspondiente de abril a agosto del 2016. El objetivo del estudio fue diseñar y aplicar Estrategias Andragógicas para conocer su incidencia en el desarrollo de la Producción Oral. La investigación enfatiza el trabajo con adultos por ende basa su metodología en principios orientados a satisfacer sus necesidades para fomentar las competencias comunicativas, conocimientos lingüísticos y pronunciación. La metodología de investigación es cuali-cuantitativa con carácter descriptivo, sustentada con investigación bibliográfica y de campo. Después de analizar los datos, se llega a la conclusión que las Estrategias Andragógicas ayudan a mejorar la Producción Oral. Es así que para que fomentar el uso de las estrategias orientadas a trabajar con adultos, el presente estudio propone la creación de un Manual Didáctico con Actividades Andragógicas para el desarrollo de la Producción Oral en el idiomas inglés.

Palabras claves: Estrategias andragógicas; producción oral; adultos; competencia comunicativas. 


\begin{abstract}
The present research was based on the application of Andragogical Strategies for the development of the Oral Production of English language of students of level A2 Centro Univesitario de Idiomas of Universidad Central del Ecuador during the corresponding period from April to August of 2016. The Objective of the study was to design and apply Andragogic Strategies to know its incidence on the development of Oral Production. The research emphasizes the work with adults; therefore, it bases its methodology on principles oriented to satisfy their needs to foster communicative competencies, language skills and pronunciation. The research methodology is qualitativequantitative with a descriptive character, supported by bibliographical and field research. After analyzing the data, it was possible to conclude that the Andragogical Strategies help to improve Oral Production. Thus, in order to encourage the use of strategies aimed at working with adults, the present study proposes the creation of a Didactic Manual with Andragogical Activities for the development of Oral Production in the English language.
\end{abstract}

Key words: Andragogical strategies; oral production; adults; communicative competencies. 


\section{Introducción}

The aim of this project is to apply communicative andragogical strategies to develop the oral production in students who are in A2 level according to the Common European Framework Reference of Languages. The speaking teaching-learning process of English is usually based on the knowledge of grammar and vocabulary; besides, classes are often teacher centered this is the reason why this project came up with the purpose of changing the way classes are carried out with the students who are adults at Centro Universitario de Idiomas. (Veytia Bucheli, 2015) (Adam, 1970)

The present research began by getting information about how adult learning works better. There is plenty of information about this topic. Malcolm Knowles was the man who created a theory based on andragogy which is focused on principles that are related to the way adults think, act and feel not only in class but also in their everyday lives. (Brandt, 1998)

With this information about adults, it was possible to find methodologies and strategies that fit adults' needs to learn. Solving problem, task based as well as collaborative methodologies were identified to design andragogical activities. (Moreno \& Quintero Acosta, 2002)

Furthermore, in order to develop A2 students' oral production, different aspects were consulted. For instance, the Communicative Language Competencies which involve the development of the linguistic knowledge, sociolinguistic field and the strategic competence to improve the oral production as a whole. (Adam, Andragogía y Docencia Universitaria, 1990)

So that A2 students can develop their Oral Production skills, it was necessary to look up information about the pronunciation of vowel as consonant sounds to help A2 students feel confident when pronouncing any words. (Alonso Chacón, 2012) (Sanz, 2010) 
Diseño y aplicación de estrategias andragógicas comunicativas en el centro universitario de idiomas de la

The present study is aimed at to determine if the use of Communicative Andragogical Strategies encourages the development of oral production on A2 students at Centro Universitario de Idiomas from April to August 2016.

\section{Methodology.}

\section{Identification of the Samples}

\section{Students Sample}

The research was carried out in Quito, at Centro Universitario de Idiomas of Universidad Central del Ecuador. The level that was taken into account was A2. The population of this level during the semester April-August 2016 was 118 students. The number of students was certainly low since the redesign of the Language Center began with 2 levels (A1 and A2) in April 2016. These students went to classes for 1 hour and 30 minutes every day from Monday through Friday in schedules in the morning, afternoon or night.

\section{Teachers Sample}

The sample of the teachers was easy to get, there were only 6 teachers working with A2 level students, so the 6 of them were asked to fill the survey.

\section{Special Groups for the Study}

So that this project could be developed, 2 groups were considered. The average age of these students was 21 years old. Both groups were evaluated orally through 2 interviews to find out their Oral Production level. One took place in April, at the beginning of the semester and the second one was carried out in August at the end of the semester. 
It is important to emphasize that these 2 groups of students were evaluated by using a rubric which took into account:

- $\quad$ Linguistic Competences

- $\quad$ Sociolinguistic Competences

- $\quad$ Strategic Competences

Determination of the Sample for students

To figure out the sample of the study, the following formula was used

$$
n=\frac{N \cdot Z^{2} \cdot \sigma^{2}}{(N-1) \cdot e^{2}+Z^{2} \cdot \sigma^{2}}
$$

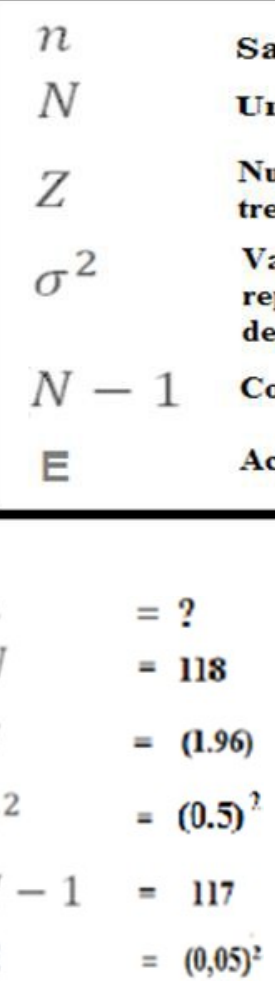


Diseño y aplicación de estrategias andragógicas comunicativas en el centro universitario de idiomas de la

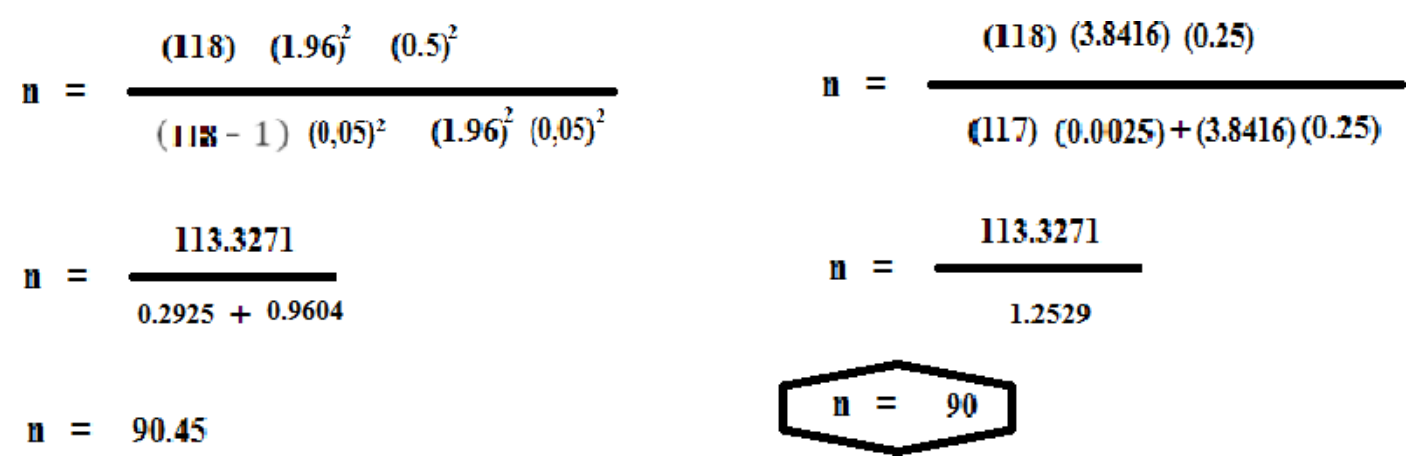

\section{Results}

Tabulation and Analysis of Students' Information

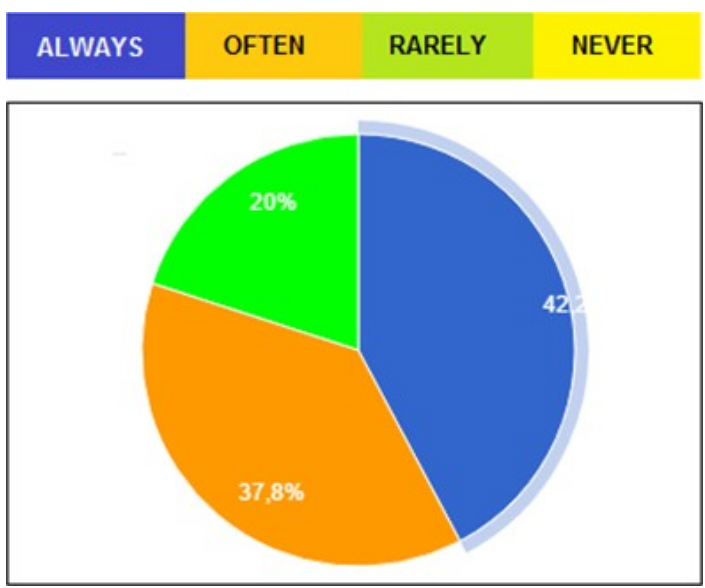

\section{Graph $N^{\circ}$ 1.- The need to know}

Question number 1 is related to the need adults have to know why they must learn something new, they want to be really convinced before making an effort when investing their time. According to the survey, most of the teachers $(80 \%)$ explain the goal of each topic which is appropriate. Nonetheless, there is a $20 \%$ of teachers who rarely give students a reason to start a new theme, the recommendation for them is to do it. Their students will have a better attitude to learn. 


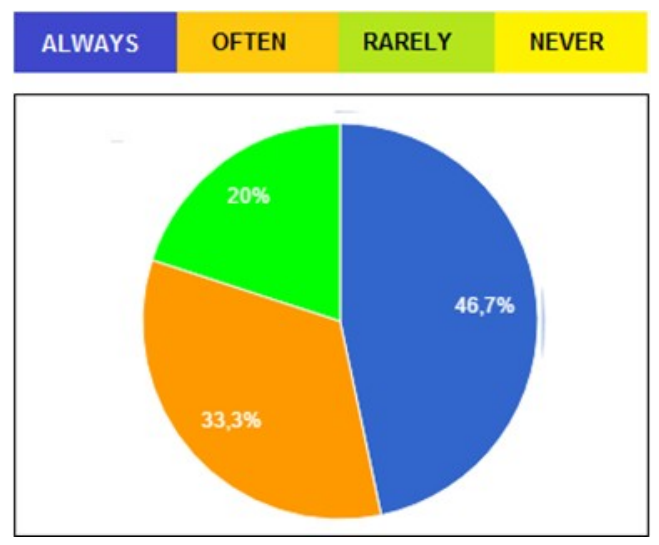

\section{Graph $N^{\circ}$ 2.- The Class Environment}

Question \# 2 is about the adult environment in class students want to feel. Students answered that $80 \%$ of teachers always or often do it which is positive for a class. University students want to be treated as adults. Even though this percentage is high, students said that teachers who rarely do it is $20 \%$. These teachers should be told to increase this frequency to create a more appropriate atmosphere for their students.

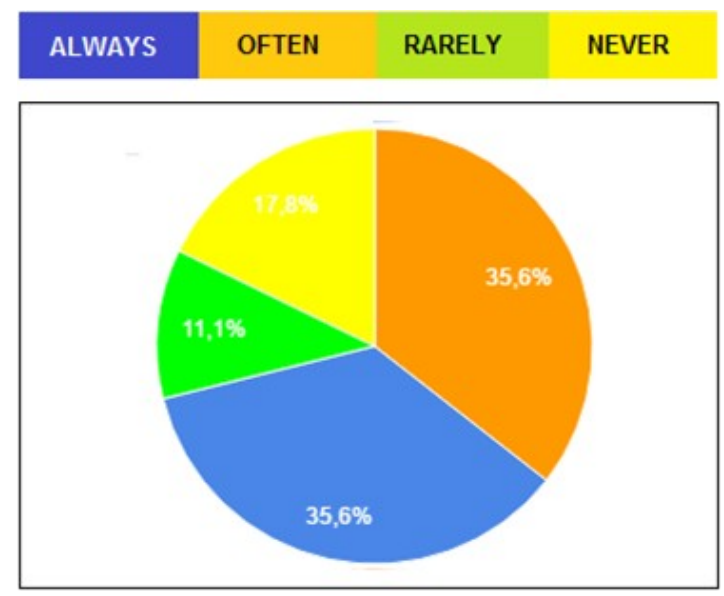

\section{Graph $N^{\circ}$ 3.- Adults' experience when planning}

Question \#3 is if teachers use adults' experience when planning. They are members of a family, workers, and friends. It is evident to see that most teachers take into account their students' 
experiences (71.2\%). It definitively makes students feel important. Adult students feel that they are an active part of the teaching-learning process. The percentage is high and suitable due to the fact that not every student's experience can be put in the syllabus. The recommendation for the teachers that rarely or never use their students' experiences $(28.8 \%)$ is to include their students' ideas for the class planning.

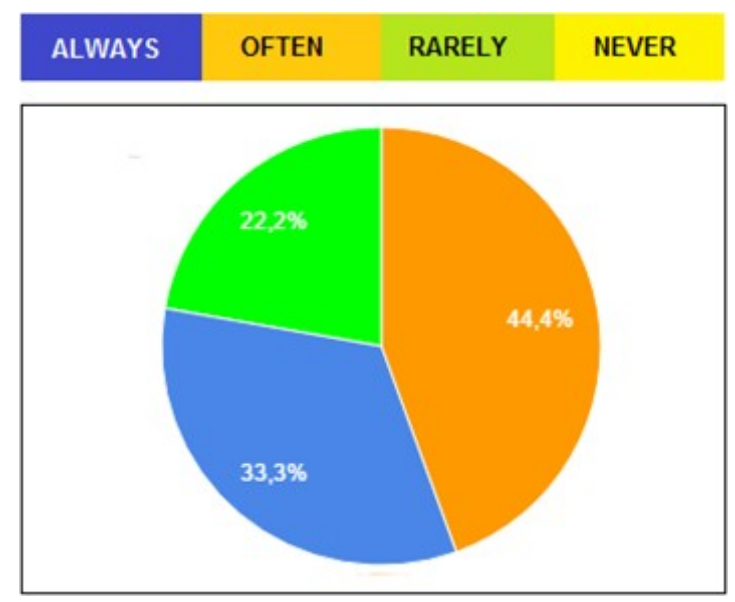

\section{Graph $N^{\circ}$ 4.- Topic Comprehension}

Question \#4 is about teachers making sure that their students have understood most of a topic before going to a new one. Students answered that $77.7 \%$ of them always or often do it. This percentage is acceptable since adult learners have developmental task stages to fulfill before going to the next level in any field. This way, teachers prevent their students from feeling disappointed and overwhelmed by the learning process. Students understand that a program that respects their pace is more important than a syllabus that does not care about them. The recommendation for teachers who rarely make sure their students have understood a topic $(22.2 \%)$ is to ask their students if they confident enough to go on to check a new topic. 


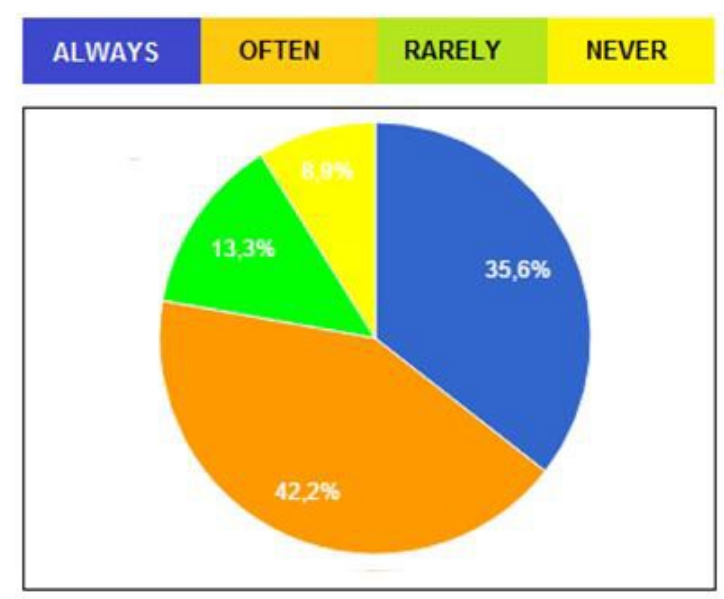

\section{Graph $N^{\circ}$ 5.- Exemplification of Topics}

Question \#5 is teachers explain students that what they are learning will be useful in their real lives in the short term. Students said that most of the teachers $(77.8 \%)$ always or often do it which is appropriate. The problem arises because $19.2 \%$ of the teachers rarely or never do it. Adults believe that to have a better predisposition to learning, they need to know that they can apply any knowledge right away, it can be in their jobs, at home or any other place. The recommendation for the teachers that rarely or never do it is to exemplify the immediate use of the topics.

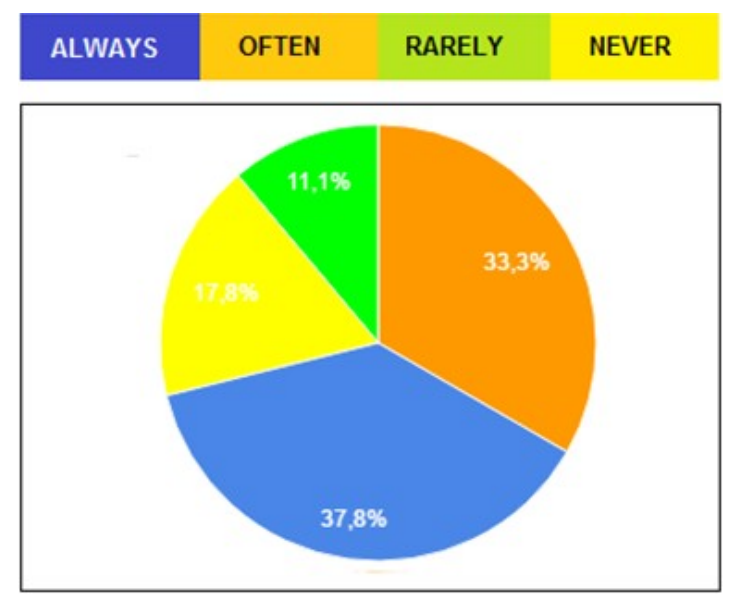

Graph $N^{\circ}$ 6.- Students`Self-Evaluation 
Question \# 6 is if teachers focus on making students evaluate themselves. Students answered most teachers (71.1\%) always or often do it which is suitable. It is the best way to promote intrinsic motivation. According to the students $(28.9 \%)$, teachers rarely or never do it. It is essential in a learning process to make students become aware of the progress they have reached. The suggestion is for this group of teachers $(28.9 \%)$ is that they should struggle a little more to design methods of self-evaluation for their students.

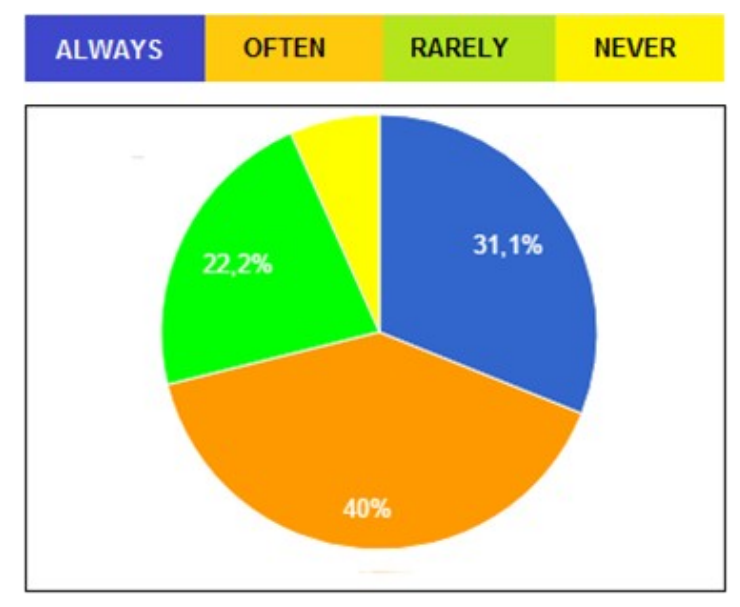

\section{Graph $N^{\circ}$ 7.- Problem Based Activities}

Question \#7 is if teachers apply activities based on problems. Students answered that $71.1 \%$ of the teachers always or often do it. This percentage is considered appropriate since students are able to develop critical thinking skills. As said before, they can share their experience to try to give a possible solution to the problem that must be as realistic as possible. $28.9 \%$ of the teachers who rarely do it should be encouraged to use these methods more often. 


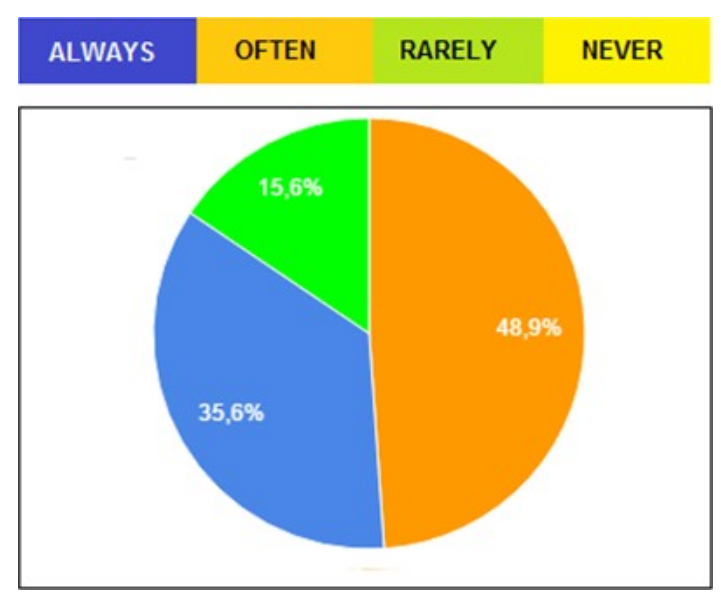

\section{Graph $N^{\circ}$ 8.- Task Learning Activities}

Question \# 8 is if teachers use task learning activities in class. Students said that $84.4 \%$ of the teachers always or often do it. The conclusion is that this percentage is suitable. These tasks have to do with realistic situations students have to deal with in their everyday lives. When task based activities are well designed, they can help students develop skills to overcome situations in different places such as: offices, homes, or any place they may be. Luckily, the number of teachers who rarely apply these strategies is $15.6 \%$. Nonetheless, they must be encouraged to use them more often.

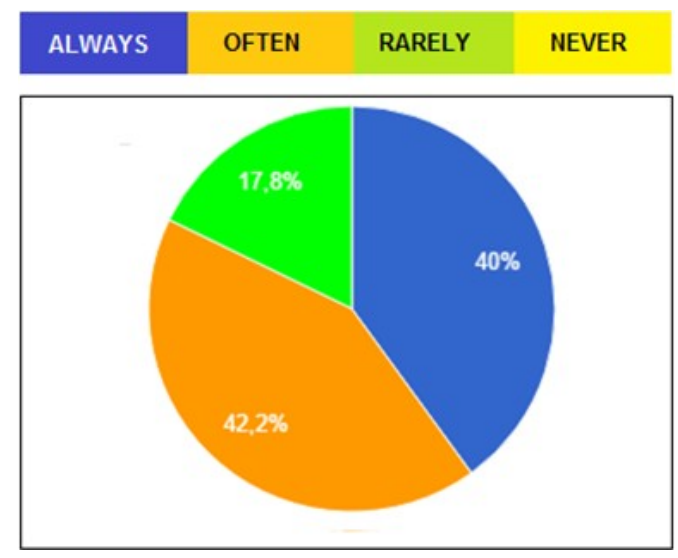

Graph $N^{\circ}$ 9.- Collaborative Activities 
Question \#9 is if the teacher uses collaborative principles when carrying speaking activities out in class. Students answered that $82.2 \%$ of the teachers always or often use these activities. The conclusion is that this fact is suitable. $17.8 \%$ of the students answered teachers rarely do it. The recommendation is tell this important these teachers to apply this type of teaching methods. Collaborative activities permit to have student centered classes. Adult learners become active members of the classroom.

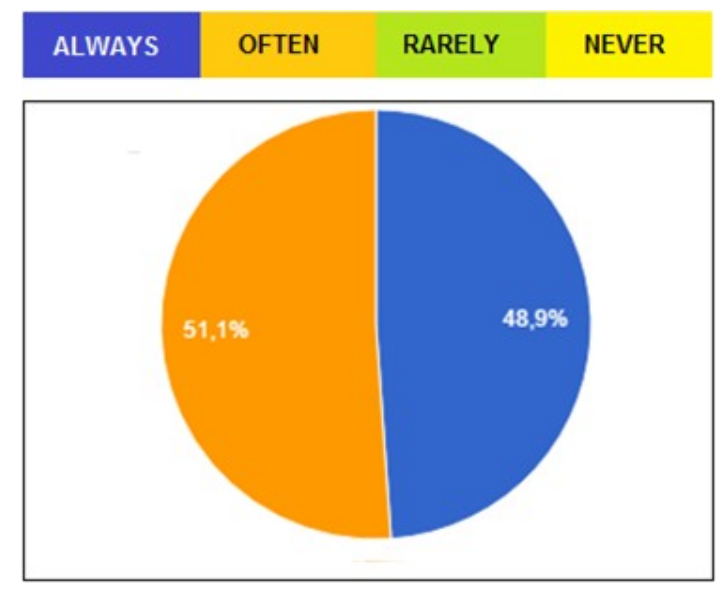

\section{Graph $N^{\circ}$ 10.- Conversational Activities}

Question \#10 is if teachers use of conversational activities. Students answered that $100 \%$ of the teachers always or often use this kind of exercises. This fact is very suitable for Centro Universitario de Idiomas. Conversational activities are considered one of the best techniques to create realistic participation. Adult learners have the possibility to know about different things. 


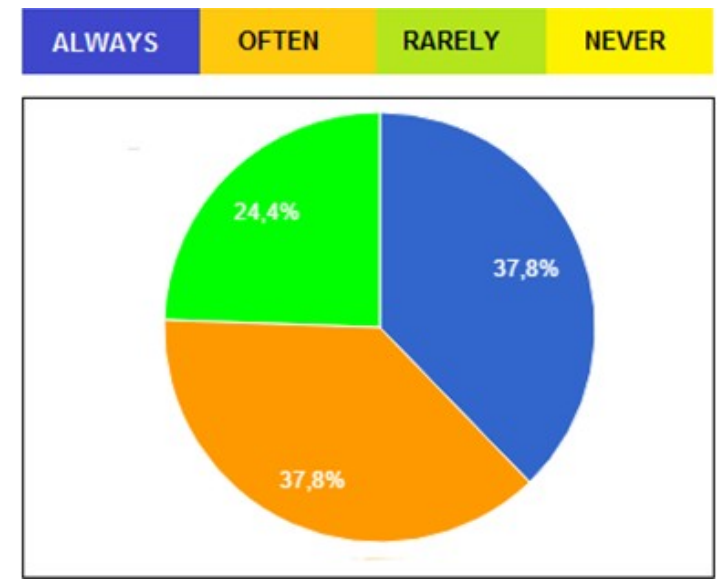

\section{Graph $N^{\circ}$ 11.- Group Discussion Activities}

Question \# 11 is if the teacher uses group discussions to develop oral production in class. According to the students $75.6 \%$ of the teachers always or often apply this strategy. It is possible to conclude that most teachers are focusing on this topic, but $24.4 \%$ of the students answered teachers rarely use this sort of activities. The recommendation for the last group is to utilize group discussions in order to make students practice group discussion to develop critical thinking skills. This activity enables learners to share their ideas and learn from each other.

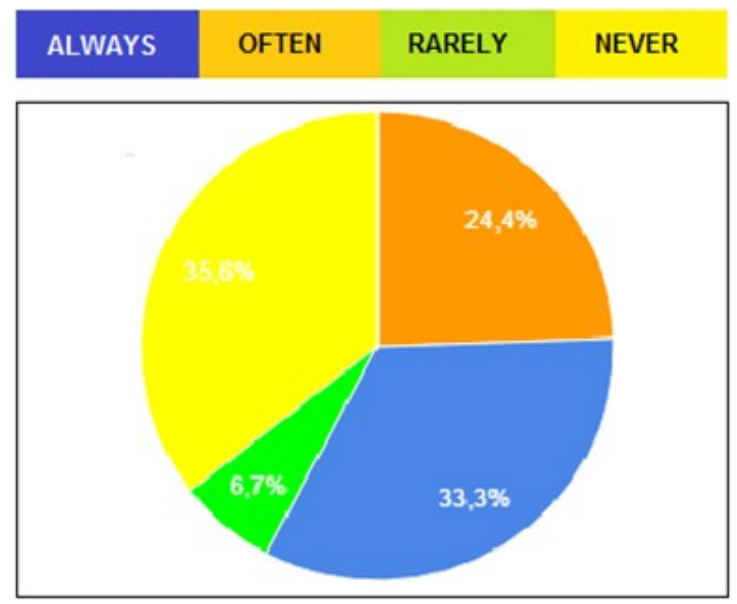

Graph $N^{\circ}$ 12.- Case Study Activities 
Question \# 12 is if teachers use case study activities to develop oral production in class. Students said that $57.7 \%$ of the teachers always or often apply these exercises. Although this percentage is not very low, it is evident that there is a big number of teachers $(42.3 \%)$ who rarely or never use case study activities. The recommendation to motivate this $42.3 \%$ to apply these kind of exercises because adult learners enjoy analyzing, thinking or working out solutions to dilemmas.

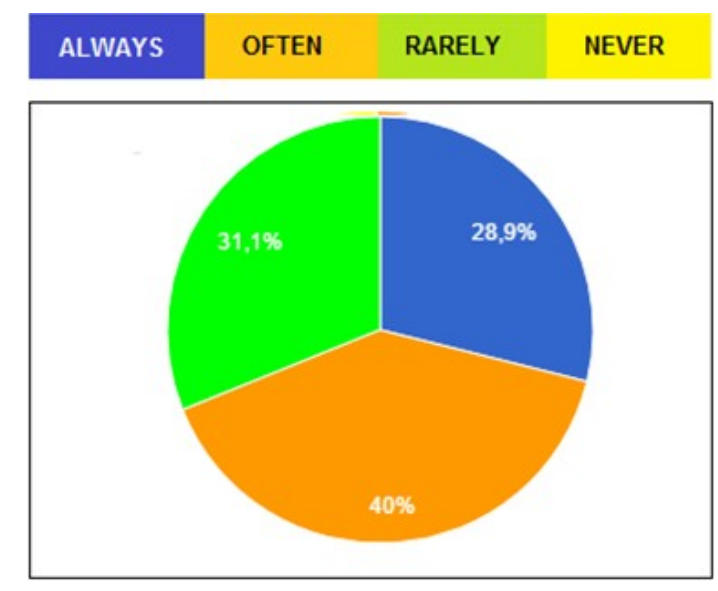

\section{Graph $N^{\circ}$ 13.- Role-Playing Activities}

Question \# 13 is if teachers use Role-playing activities in class. It is possible to see that students think that $78.9 \%$ of the teachers always or often apply them which is considered suitable. $31.1 \%$ of the students believe that teachers rarely do it. Role-playing tasks are important in the learning process since students are encouraged to use their imagination and creativity. Students take most of the control of the activity. The only recommendation could be to motivate teachers who rarely carry out these exercises to use role-playing activities. Students have a good time and the class environment improves. 


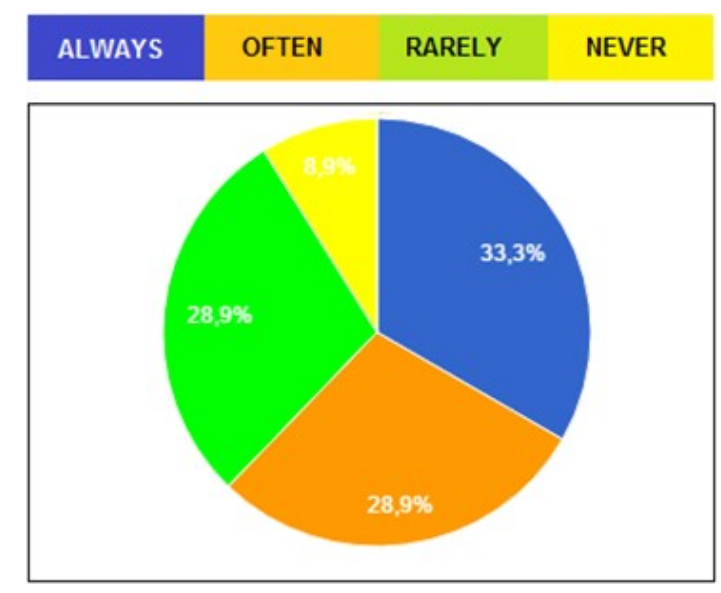

\section{Graph $N^{\circ}$ 14.- Oral Presentations}

Question \# 14 is about the use of oral presentations in class. According to what students answered $72.1 \%$ of the teachers always or often make their students prepare oral presentations. $37.8 \%$ rarely or never do it. Oral presentations are important in the learning process since students develop speaking skills. The recommendation could be to motivate teachers who rarely or never carry out these exercises.

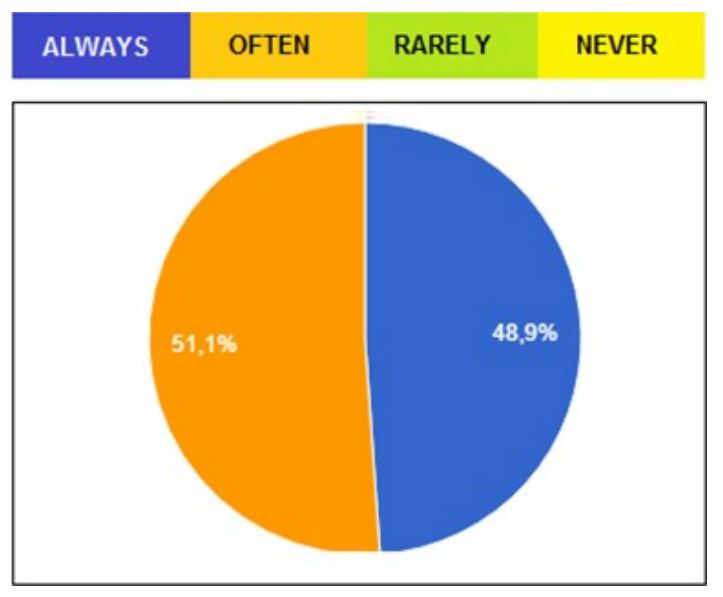

Graph $N^{\circ}$ 15.- Grammar and Vocabulary 
Diseño y aplicación de estrategias andragógicas comunicativas en el centro universitario de idiomas de la

Question \# 15 is if teachers focus on grammar and vocabulary when developing students' oral production. Students think that $100 \%$ of the teachers always or often do it. The conclusion is that the teachers understand the importance of communicating correctly. Adult learners work, they have a professional life. They need to use correct sentence structures and have good vocabulary for serious facets of life.

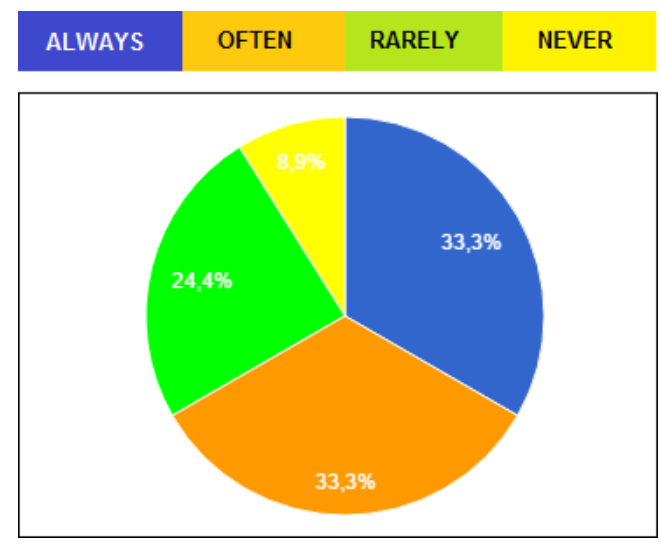

\section{Graph $N^{\circ}$ 16.- Socio-Cultural Aspects}

Question \# 16 asks if teachers focus on social and cultural aspects when helping students develop oral production. Students answered that $66.6 \%$ of the teachers always or often do it. It is possible to see that most teachers teach how to express ideas from social and cultural aspects. The problem arises because $33.4 \%$ of the students answered that teachers rarely or never do it. Adult learners need to be skillful enough to have good conversations. 


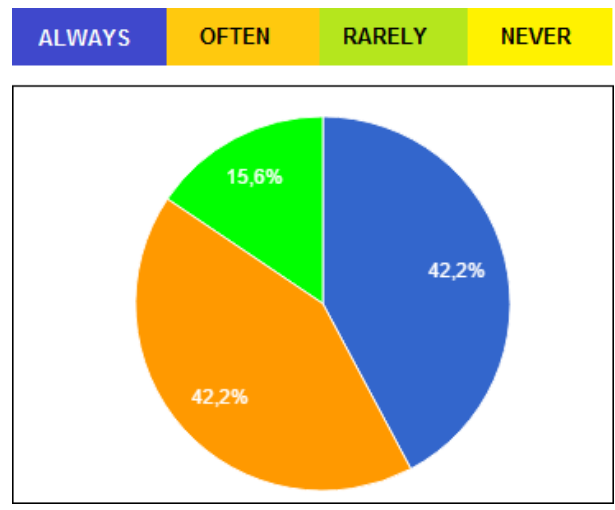

\section{Graph $N^{\circ} 17 .-$ Cohesive and Coherent Ideas}

Question \# 17 is if teachers make students develop cohesive and coherent ideas when speaking. $84.4 \%$ of students answered that teachers always or often pay attention to these topics. It is a very high and suitable percentage. On the other hand, only $16.4 \%$ of the students said that teachers rarely make them practice cohesion and coherence or oral production. Connecting and relating ideas one with one another is essential when communicating orally.

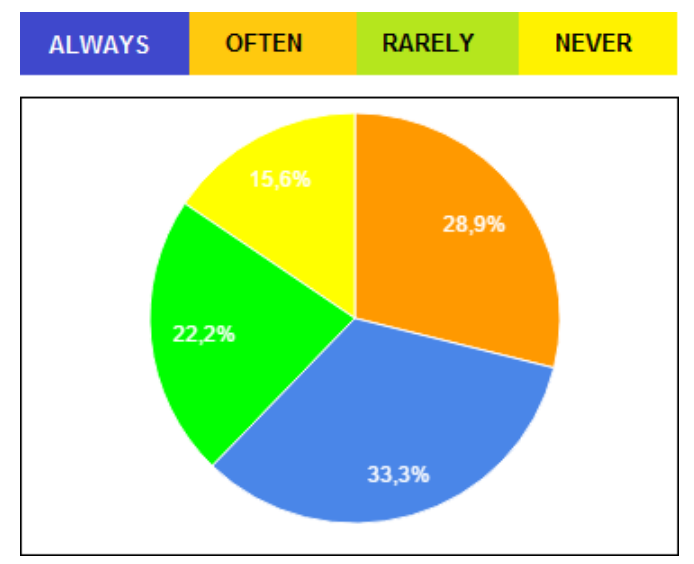

Graph $N^{\circ} 18 .-$ conversational Strategies

Question \# 18 has to do with the promotion of conversational strategies in class. According to the students only $61.2 \%$ of the teachers always or often promote them. On the other hand, $38.8 \%$ of the students said that their teachers rarely make them practice conversational strategies. Students 
normally find it difficult to communicate fluently. They often make pauses because they do not know the right words or have lack of fluency. Teachers who rarely or never help with conversational strategies should make their students practice these topics.

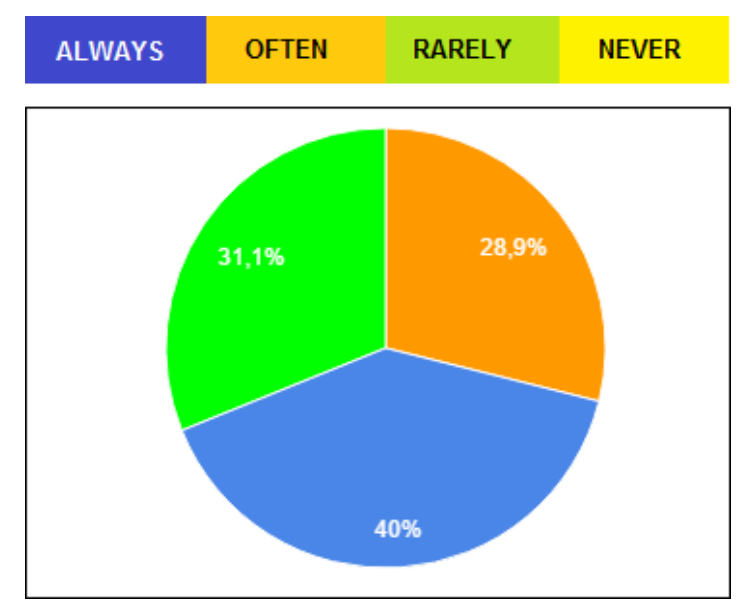

\section{Graph $N^{\circ}$ 19.- Types of Language}

Question \# 19 has to do with the voice modulation that comes with speaking sequence of sounds which students can adopt depending on who they are speaking with. Students answered that $68.9 \%$ of the teachers focus on intonation practice which can be considered suitable. $31.1 \%$ of the students said they rarely do it. The recommendation for teachers is that they should motivate their students to show excitement, anger, surprise, etc. when communicating.

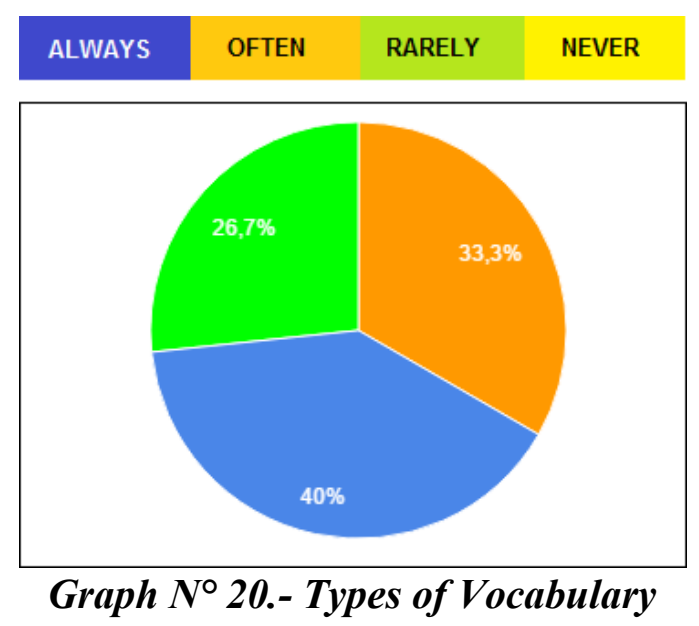


Question \# 20 is about the use of different types of lexicon among students so that they can use the appropriate vocabulary depending on who they are talking to. Students said that $73.3 \%$ of their teachers always or often focus on this topic. $26.7 \%$ of the teachers rarely do it. It is possible to notice that the group that rarely does it is representative. Then, this group of teachers needs to consider that adult learners will face a variety of situations in their lives, knowing a lot vocabulary can help them overcome them in their professional lives or under any circumstances.

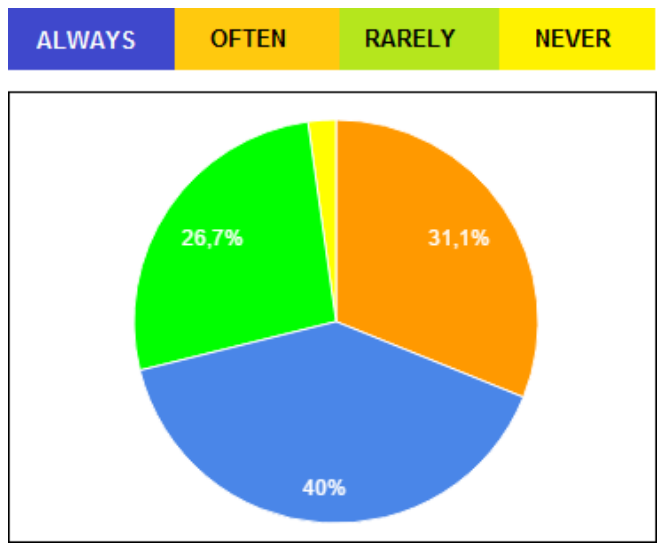

\section{Graph $N^{\circ}$ 21.- Consonant and Vowel Sounds}

Question \# 21 is if the teachers help students know how to pronounce vocal and consonant sounds. Students said that $71.1 \%$ of the teachers always or often check vowel and consonant pronunciation. This is considered appropriate that most teachers worry about this topic. On the other hand, $28.9 \%$ of the students said their teachers rarely or never do it. This group of teachers should be recommended to work on this field. 


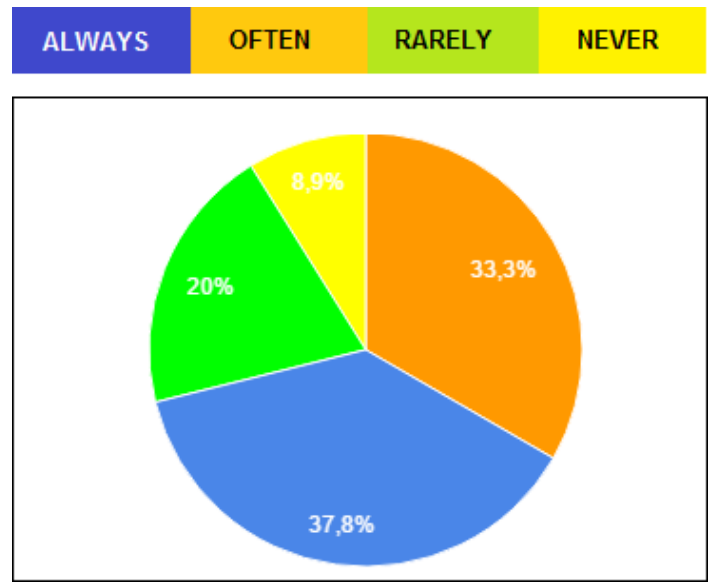

\section{Graph $N^{\circ} 22 .-$ Pauses and Oral Fluency}

Question \# 22 is about the use of appropriate pauses and practice of oral fluency. According to the students $71.1 \%$ of teachers always or often work on these topics. This percentage is appropriate for the Language Center. $28.9 \%$ of the teachers do not focus on these topics suitably. The conclusion is that most teachers promote the use of appropriate pauses and the practice of fluency for the development of oral production. The other teachers who rarely or never do it should be recommended to do it more often.

\section{Conclusions}

$83 \%$ of teachers rarely prepare tools to make their students evaluate themselves so that students can know their progress.

$66 \%$ of the teachers rarely or never use Case Study activities which permit students to develop critical thinking while they develop Oral Production.

Only $50 \%$ of teachers promote the use of strategies to develop Oral Production. It means that students do not often know what to do when they do not remember vocabulary or do not know how to express their ideas. 
Most teachers use Communicative Andragogical Strategies; however, the results are not as satisfactory as they should be.

\section{Recommendations.}

Teachers should prepare rubrics or tools that permits students evaluate themselves continuously so that they get to know how to improve in their performance in class.

Teachers should use case study activities, they are very useful to make students practice their speaking and get a critical mind.

Teachers should teach students how to solve problems while speaking. It can be done through pauses or by using appropriate expressions.

Teachers should use Communicative Andragogical Strategies more often so that students become more comfortable with its use and to get better results with students.

Teachers should have a course on how to create andragogical activities to take advantage of the information they about their students. They can personalize the tasks according to their students needs.

\section{Bibliography.}

Adam, F. (1970). Andragogía: ciencia de la educación de adultos. Caracas: Federación Interamericana de Educación de Adultos (FIDEA).

Adam, F. (1990). Andragogía y Docencia Universitaria. Caracas: Federación Interamericana de Educación de Adultos.

Alonso Chacón, P. (2012). La Andragogía como disciplina propulsora de conocimiento en la educación superior. Revista Electrónica Educare, 16(1), 15-26.

Brandt, J. (1998). Andragogía: propuesta de autoeducación. Los Teques: Tercer Milenium.

Moreno, F., \& Quintero Acosta, M. (2002). La Educación Andragógica: una Estrategia frente a los Problemas Ambientales. Actualidad Contable Faces, 5(5), 7-22. 
Diseño y aplicación de estrategias andragógicas comunicativas en el centro universitario de idiomas de la Universidad Central del Ecuador

Sanz, M. (2010). Competencias cognitivas en Educación Superior. Madrid: Narcea.

Veytia Bucheli, M. (2015). Estrategias andragógicas para estudiantes de posgrado a partir de procesos de mediación tecnológica. Atenas, 3(31), 45-54. 